原著 睡眠時刻の推移にともなう覚醒レベルの変化と その後の睡眠のパターンとの関係

斉藤 良夫*, 松 本一弥**

\title{
RELATION BETWEEN CHANGE IN AROUSAL LEVEL WITH SHIFT OF SLEEPING TIME AND SUBSEQUENT SLEEP STAGE PATTERN
}

\author{
Yoshio SAITo* and Kazuya Matsumoto**
}

\begin{abstract}
The relationship between decrease in cerebral arousal level and sleep stage pattern was examined when a cycle of $22 \mathrm{~h}$-wake and $8 \mathrm{~h}$-sleep was repeated four times. The subjects of the experiment were six healthy male university students.

The results of the experiment showed that the period between the time when the average score of Stanford Sleepiness Scale (SSS) reached point four (a little foggy) and the rising time was gradually decreased by repetition of the $22 \mathrm{~h}$-wake and $8 \mathrm{~h}$-sleep cycle. It was also found that the average score for the 6th experimental day after the third cycle was significantly increased, compared with that for the 1 st $22 \mathrm{~h}$ waking period. These results show that the cerebral arousal level, which was indicated on the scores of SSS, was gradually decreased under the present experimental wake-sleep condition. The day-to-day variation of critical fusion frequency showed a tendency similar to that of SSS, demonstrating a gradual decrease in arousal level.

On the other hand, stage 4 sleep (S4) was significantly increased during sleep after the 1st $22 \mathrm{~h}$ waking period, compared with baseline sleep after $16 \mathrm{~h}$ waking time. However, a significant increase in S4 was not seen during the sleeping periods in the second to the fourth cycles of 22 $\mathrm{h}$-wake and $8 \mathrm{~h}$-sleep, compared with that during the sleep after the $1 \mathrm{st} 22 \mathrm{~h}$ waking period.

These results suggest that, with respect to the 1 st cycle of $22 \mathrm{~h}$-wake and $8 \mathrm{~h}$-sleep, the increase in S4 was related to the decreased level of arousal which was caused by a long prior wakefulness of $22 \mathrm{~h}$. However, our results also suggest that a further decrease in arousal level due to the repetitive cycles did not increase the amount of S4.
\end{abstract}

Key words: fatigue; arousal; stage 4 ; Stanford Sleepiness Scale

\section{I.は じめに}

疲労は産業労働や実験的に負荷された作業の遂行によ って発生し，休息や睡眠によって回復するといわれてい る、実際，作業遂行によって起こった生理的諸機能の低 下や疲労感の訴えの増加は，昼休みなどの大休款や実験 的に插入される休愁によってそれぞれ回復の現象があら われることはよく観察されることである.このことはま

* 中央大学文学部心理学研究室

** 杏林大学医学部衛生学教室

昭和 62 年 11 月 17 日受付

* Department of Psychology, Chuo University

** Department of Hygiene, Kyorin University School of Medicine

Received for publication, November 17, 1987
た，1日の労働とその夜の自宅休息や睡眠との関係につ いても認められる.多くの疲労研究は，夜間にとられる 睡眠の疲労回復効果の重要性を指摘してきた1,2).

労働や作業の遂行に上る疲学の発現・進展過程と休 息・睡眠によるその回復過程との関倸は，いままで前者 の過程についての研究が数多く行われてきたのにたいし て，後者の過程についての情報が不足していたために十 分明らかにすることができなかった．しかし，最近の睡 眠脳波の研究によってようやくその解明の端緒が開かれ るよらになった。

睡眠脱波に関する従来の諸研究を概観すると，昼間ま たは夜間に被験者に運動や精神的作業を負荷させた場 合それらを負荷させない条件と比較して，その夜また は昼間にとられる睡眠中の Slow Wave Sleep（以下 
SWS と略す）や S4（ステージ4, 以下睡眠の各ステー ジはこのように記す）の出現量が增大することを明らか にしよらとする方法諭がとられている. その場合, それ らの負荷条件下で被験者の疲労がどのような状態である かについて調へてている研究はきわめて少ない，そして， このことは, 長時間覚醒条件とその後の睡眠との関係を みる研究にる当てはまることである.

従来の多くの研究では, 強い運動負何後や䉼眠下での 運動後の睡眠中に SWS P4 の瀕著な增大がみられる 一方で、出)，精神的負荷をかけた実験では，それらが增大 する結果を示したものが少ない（5,6).

一方, SWS や S4 の出現量の程度は断眠によって影 響されることが明らかにされ，先行覚醒時間（prior wakefulness）が長くなると，それらは明確飞增大する ことが知られている7,8)。このことは，断眠によって生 じる大脳皮質の覚醒レベルの低下とことに S4 の增大が 関係していることを示唆している.

したがって，疲労研究の場合，まず明らかにすべきこ とは，作業負荷や長時間覚醒によって被験者が覚醒レペ 几の明らかな低下を示すよらな疲学状態一と变わってい くときに，その後にとられる睡眠で SWS や 54 に增大 の傾向がみられるかどらかといらことである。

著者らは，1日の陲眠・覚醒りズムを時刻的に推移さ せ 22 時間の覚醒を繰り返したときの覚醒レベルの变化 とその後にとられる睡眠中の船波のパターンの变化につ いて調べた.

\section{II. 実 験 方 法}

\section{1. 被験者}

正常な睡眠・覚醒サイクルの生活を送っている某大学 の健康な男子学生 6 名（年柃 $21 \sim 24$ 歳；平均 22.0 歳） を対象者にした。

\section{2. 実験計画}

その詳細については，すでに別報》で報告されている ので,ここではその概略を述べる.最初の第1日は被駼 者に 8 時間睡眠 $(00: 00 \sim 08: 00)-16$ 時間觉醒の正常 生活を実験室で送らせた後，第 2 日から毎日 6 時間ずつ 生活時刻を移動させ，生活時間を 30 時間，すなわら覚 醒期 22 時間，睡眠期 8 時間の生活を送るようと計画し た.この計画では, 実験第 7 日には第 1 日の正常生活時 間帯に戻ることになる.この間にとられる各睡眠の時間 帯は, $06: 00 \sim 14: 00,12: 00 \sim 20: 00,18: 00 \sim 02:$ 00,抢よび 00 : 00 08:00 の順になる. 第 8 日は回復 日として，第 7 日と同し睡眠と覚醒の時間生活を送るよ らにした，睡眠脳波の分析では，第 2 日の睡眠を基準 夜, をた第 8 日の睡眠を回復夜のものとした (Fig. 1 参 照).

\section{3. 実験日の生活時間の構成}

（1）睡眠時間：前述のように 8 時間睡眠とし，各人シ ールド・防音された脳波測定室で就寝させ，就寝から起 床までの睡眠ポリグラムを記録した．被験者は就寝 20 分前に電極類を装着し， 3 分前には測定室に入った，睡

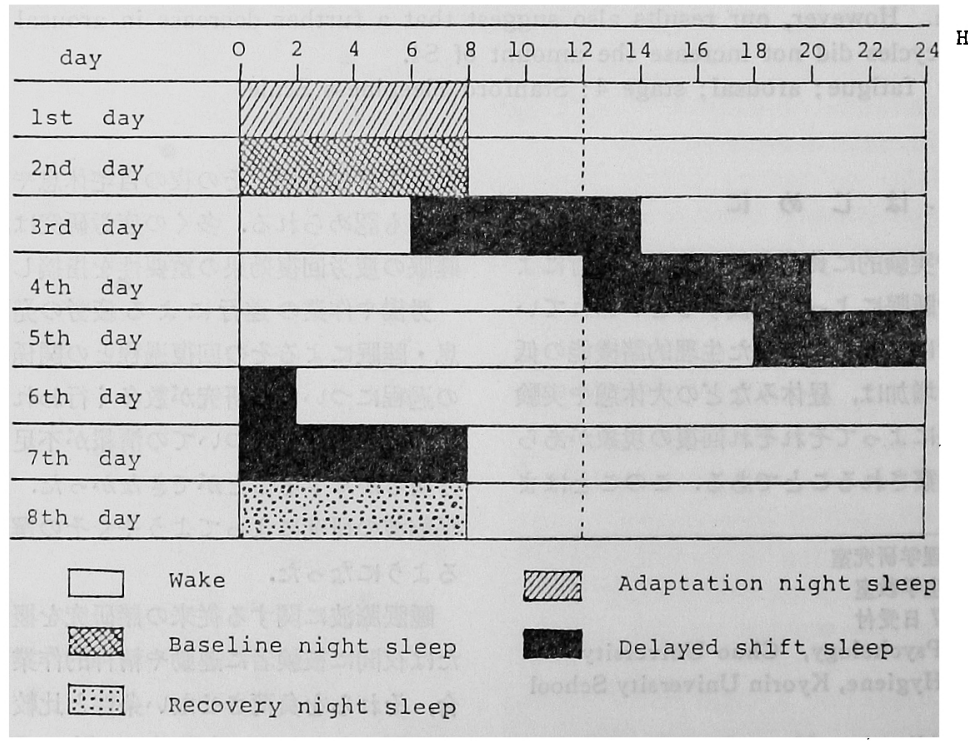

Fig.1. Schedule of experiment. 
Table 1. Mean total sleep times, mean latencies of sleep, S 3, S4 and REM, and mean sleep cycle lengths for each of the experimental days ( $\mathrm{min}$ ).

Mean (SD)

\begin{tabular}{|c|c|c|c|c|c|c|c|}
\hline & \multirow{2}{*}{\multicolumn{2}{|c|}{ 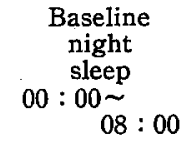 }} & \multicolumn{4}{|c|}{ Delayed shift sleep } & \multirow{2}{*}{$\begin{array}{c}\text { Recovery } \\
\text { night } \\
\text { sleep } \\
00: 00 \sim 08: 0 \\
08: 0\end{array}$} \\
\hline & & & $\begin{array}{c}\text { 3rd day } \\
06: 00 \sim \\
14: 00\end{array}$ & $\begin{array}{c}4 \text { th day } \\
12: 00 \sim 20: 00 \\
20:\end{array}$ & $\begin{array}{c}5 \text { th-6th day } \\
18: 00 \sim 2 \\
02: 00\end{array}$ & $\begin{array}{c}7 \text { th day } \\
00: 00 \sim 08: 00 \\
08\end{array}$ & \\
\hline Total sleep time & 456.3 & $(17.1)$ & $442.5 \quad(24.3)$ & $466.5(10.0)$ & $461.5 \quad(16.2)$ & $468.3 \quad(14.3)$ & $460.5(14.6)$ \\
\hline Sleep latency & 23.5 & $(11.4)$ & $8.5^{*}(1.7)$ & $6.3^{* *}(1.7)$ & $5.8^{* *}(1.3)$ & $7.5^{*}(2.6)$ & $15.5(13.2)$ \\
\hline S3 latency & 37.0 & $(16.2)$ & $16.3^{*}(3.4)$ & $10.5^{* *}(1.3)$ & $9.3^{* *}(1.5)$ & $13.3^{* *}(3.1)$ & $24.5(17.0)$ \\
\hline S 4 latency & 41.5 & $(15.8)$ & $20.0^{*}(3.6)$ & $14.3^{* *}(1.5)$ & $13.0^{* *}(1.4)$ & $17.3^{* *}(2.4)$ & $33.3(18.1)$ \\
\hline REM latency & 78.5 & (13.8) & $50.7^{* *}(14.8)$ & $65.5^{*}(18.2)$ & $69.3 \quad(12.4)$ & $69.5 \quad(8.7)$ & $69.3(8.1)$ \\
\hline Sleep cycle length & 93.6 & (19.9) & $83.2 \quad(15.1)$ & $80.0 \quad(20.3)$ & $84.0 \quad(17.6)$ & $91.1 \quad(16.8)$ & $89.4(18.1)$ \\
\hline
\end{tabular}

$* p<0.05,{ }^{* *} p<0.01$, significantly different from the baseline night sleep (one-tailed $t$-test).

眠中の湘定は，脳波，眼球運動，筋電図で， Rechtschaffen ら 103 の方法によって電極を配置し，さらに心電 図と呼吸曲線を記録した. 睡眠段階の判定は同じく

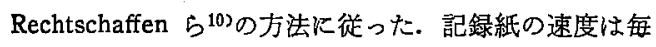
秒 $3 \mathrm{~cm}$ とし, 睡眠段階の判定は 20 秒間ごとの記録に ついて行い，最後は分単位で集計を行った。なお，脳波 の測定は，6人の被験者の5ち4人について行われた。

（2）拘束時間：各実験日ともに起床直後から次の就漫 1 時間前までの間（各食事時間の 1 時間を除く），1時 間ごとにスタンフォード眠気尺度およびフリッカー值を 测定しまた ないし2 時間ごとに下記に述べる種々の 生理心理機能の測定を行った. 湘定は 10〜15 分間の座 位安静状態を保持させた後行われた。

(A) スタンフォード眠気尺度 (Stanford Sleepiness Scale; SSS) : Hoddes ら ${ }^{11}$ の作成した原案の日本語訳 を作りそれを用いた．この尺度は Thurstone の等現間 隔法にもとづいて得点 1 （生き生さしている，とてる活 発）から７（汪とんど眠りそうな状態，目を覚まそうと する努力がもらできないまでの 7 評点段階から成り立 っている. 得点が高いほど覚醒レベルが低いことにな る. 各測定時には被験者に用紙を渡してチェックさせ た.また各実験日の睡眠から起床した直後にもチェック させだ.

（B）フリッカー值：川崎エレクトロ社製の自記式フリ ッカー装㯰によって各測定時に連続して 5 回測定した.

集計に当たっては最大值と最小値を棄却して, 残りろつ の平均值を求めた。

さらに，覚醒時間中には体温，脈拍数，血圧，近点距 崔などの生理機能, 疲労自覚症状（日本産業衛生学会・ 産業疲労研究会橴の“自覚症状しらべ”使用)，単純打
よび 8 選択反応時間，一位加算量などの測定を $〜 2$ 時 間の間隔で行った。

実験期間中の被験者の食事時間を含む生活の仕方，お よび実験日の経過にとむならフリッカー值，体温，脈拍 数, 波労自覚症状, 8 選択反応時間など結果について は，別報》を参照されたい。

\section{III. 結 果}

\section{1. 睡眠脳波の変化}

Table 1 は, 実験期間中の各睡眠期について, 全睡眠 時間，各睡眠段階の潜時占よび睡眠周期の長さを示した るのである. 全睡眠時間は実験期間中大きな変化を示さ ず，睡眠率は 92.2\%（第 3 日） 97.6\%（第 7日）の範 囲であった，入眠潜時では，二元配置の分散分析で実験 期間全体にわたって睡眠期の間に有意な差が認められな かった（ $p>0.05, d f=5,15$; 自由度については以下同 し).しかし，実験第 3 日から第 7 日をでの入眠潜時は， 基準夜にくらべていずれる $t$ 検定で有意に短縮した（第 4 日と第 $5 \sim 6$ 日 $p<0.01$, 第 3 日と第 7 日 $p<0.05$ ； ともに片側検定, $d f=6$, 自由度については以下同じ). 回復夜では基準夜より8分の短縮であったが，有意な差 はみられなかったまた，睡眠時刻を推移させた長時間 覚醒下の第 3 日から第 7 日までの入眠潜時の変化につい ては，第3日から第 5〜6日までの間はわずかに短縮し ていく傾向がみられたが，第7日には若千延長した.

S3 および S4の各睡眠潜時についての実験期間中の変 化については，S3 の潜時は入眠潜時と同しく有意差が 認められなかった（ $p>0.05 ） か ゙, S 4$ の潜時には実験期 間全体にわたる变化について有意差が認められた（ $p<$ 0.05). また，S4 の潜時は，第 3 日から第 7 日までは基 
Table 2. Mean sleep stage data for each of the experimental days (min).

Mean (SD)

\begin{tabular}{|c|c|c|c|c|c|c|c|}
\hline \multirow{2}{*}{$\begin{array}{l}\text { Sleep } \\
\text { stage }\end{array}$} & \multirow{2}{*}{\multicolumn{2}{|c|}{$\begin{array}{c}\begin{array}{c}\text { Baseline } \\
\text { night } \\
\text { sleep }\end{array} \\
00: 00 \sim 08: 00\end{array}$}} & \multicolumn{4}{|c|}{ Delayed shift sleep } & \multirow{2}{*}{ 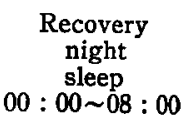 } \\
\hline & & & $\begin{array}{c}\text { 3rd day } \\
06: 00 \sim 14: 00\end{array}$ & $\begin{array}{l}\text { 4th day } \\
12: 00 \sim 20: 00\end{array}$ & $\begin{array}{l}\text { 5th-6th day } \\
18: 00 \sim 02: 00\end{array}$ & $\begin{array}{c}\text { 7th day } \\
00: 00 \sim 08: 00\end{array}$ & \\
\hline 1 & 16.7 & $(5.0)$ & $17.5(5.8)$ & $22.2 \quad(8.0)$ & $19.3 \quad(5.4)$ & $20.4 \quad(14.2)$ & $13.8(8.7)$ \\
\hline 2 & 218.8 & (28. 5) & $151.5^{* *}(12.1)$ & $183.4^{*}(23.3)$ & $183.8^{*}(34.5)$ & $205.5 \quad(25.3)$ & $217.8(22.8)$ \\
\hline 3 & 37.3 & (15.4) & $34.5 \quad(14.8)$ & $33.3 \quad(6.2)$ & $36.1 \quad(5.4)$ & $35.1 \quad(8.5)$ & $39.0(12.7)$ \\
\hline 4 & 67.5 & $(5.3)$ & $81.5^{*}(13.8)$ & $83.8^{*}(14.8)$ & $88.0^{* *}(8.7)$ & $82.0^{*}(15.1)$ & $62.5(13.3)$ \\
\hline REM & 116.0 & $(7.6)$ & $157.5^{* *}(19.2)$ & $143.8^{* *}(12.2)$ & $134.3^{*}(18.2)$ & $125.3 \quad(12.5)$ & $127.4(22.8)$ \\
\hline
\end{tabular}

${ }^{*} p<0.05,{ }^{* *} p<0.01$, significantly different from the baseline night sleep (one-tailed $t$-test).

準夜とくらべて有意に短縮し（第 3 日， $p<0.05$ ，第 4 日から第 7 日まで $p<0.01)$, 回復夜でる短縮の傾向で あったな，有意な善は認められなかった，また，第 3 日 から第 7 日までの変化む，入眠潜時のそれと類似してい た. S3 の潜時の第 3 日から第 7 日までの変化について は，上述の S4 の潜時の結果ときわめて類似していた.

REM 潜時は，実験期間中の睡眠期の間に有意な差が 諗められた $(p<0.05)$ ．基準夜と比較すると，第 3 日 は有意哣㴼し $(p<0.01)$ ，それは第4日まで続いた $(p<0.05)$. 第 $5 \sim 6$ 日と第 7 日西短縮する傾向にあっ たが，有意な差はみられなかった，睡眠周期の長さは， 第 3 日から第 7 日まで基凖夜とくらべてわずかに短縮し ていたが，実験期間中の睡眠期の間には有意な差はみら れなかった。

Table 2 は, 各睡眠段階の出現量を実験期間中の嘎眠 期別に示したものである.分散分析の結果，実験期間全 体にわたって睡眠期間に有意差を認められたのは S2 $(p<0.05) ， \mathrm{~S} 4(p<0.05)$ および REM 睡眠 $(p<$ 0.01) であった.

長時間覚醒下の第 3 日から第 7 日までの $\mathrm{S} 4$ は，基準 夜にくらべていずれも有意に増加した（第 3 日，第 4 日，第 7 日 $p<0.05$; 第 $5 \sim 6$ 日 $p<0.01$ ）. 第 3 日は 基準夜とくらべて 14 分の増加であった．第 3 日から第 7 日までの変化では，第 $5 \sim 6$ 日まで增加するが，その 差はわずかであり，回復夜にはもとのレベルに戻った。 各睡眠期における全睡眠時間中に占める S4 の割合は， 基準夜が平均 14.8\% であるのにたいし，第 3 日から第 7 日まではそれぞれ 18.4，18.0，19.1，17.5\% で，第 3日以降は汪とんど変化はなかった。また，回復夜は 13.6\%であった，一方，S3 は，S4 と異なり，䨋験期 間中ほとんど变化しなかったまた，SWSも同様な結 果であった。

REM 䀯眠は，S4 と同じく第3日，第4 日および第
5〜6日に基準夜とくらべていずれも有意な増加を示し た（第 3 日と第 4 日 $p<0.01$; 第 $5 \sim 6$ 日 $p<0.05$ ). 第 7 日も增大したが有意ではなかった. 22 時間覚醒下の第 3 日から第7日までの REM 睡眠量については，第3 日 が最も多く，々の後第 7 日にかけて約 10 分ずつ漱次減 少する傾向を示した

一方，S2 は，S4 や REM と異なって，第 3 日，第4 日扰よび第 5 ～6 日でいずれも有意な減少を示した（第 3 日 $p<0.01$; 第 4 日と第 $5 \sim 6$ 日 $p<0.05)$. 第 7 日 も減少したが，有意な美はみられなかった，そして，回 復夜にはもとのレベルに復帰した。

Table 3は，各実験日の睡眠期を第 1 (前)，第 2 (中)， 第 3 (後)の各期に 3 等分 L，その各期間に 含まれる S4 と REM 睡眠の出現量を示したものである. まず $\mathrm{S4}$ は，どの倕眠期でも睡眠前期にもっとも多く，ついで中 期，後期の順に減少する傾向が明らかであった。したが って，S4はどの睡眠期にあっても，入眠後 3 時間以内に 多く出現していることになる．実験期間中の睡眠前期の S4 の出現量の変化については，実験第 3 日から第 $5 \sim$ 6 日にかけては，基準夜と比較して有意に增加する傎 を示すが，第 7 日から回復夜にかけては減少した．実験 期間中のこのよらな変化は, Table 2 に示した S4 の全 睡眠時間中の出現量の変化と類似していた。

一方，REM 睡眠については，その出現は睡眠後期に もっとも多く，前期ではもっとも少なかった（第 3 日を 除〈). この前期の REM 出現量の実唭期間中の変化に ついては，実験第 3 日にもっとる多いが，その後は漸减 して，回復夜には基準夜のレペルに戻る傾向があった （第 3 日と第 4 日の出現量は基準夜のそれとくらぺて有 意な増加).これと同じ傾向は，睡眠中期における出現 量の変化にもみられた。

2. スタンフォード眠気尺度の得点の变化 実験日にともなう6名の被験者の平均得点の変化を示 
Table 3. Mean times spent in S4 and SREM during 1st, 2nd and 3rd one-third periods of sleep times for each of the experimental days ( $\mathrm{min}$ ).

Mean (SD)

\begin{tabular}{|c|c|c|c|c|c|c|c|c|}
\hline & \multicolumn{4}{|c|}{ Stage 4} & \multicolumn{4}{|c|}{ Stage REM } \\
\hline & & lst & 2nd & 3rd & & lst & 2nd & $3 r d$ \\
\hline \multicolumn{9}{|l|}{ Baseline night sleep } \\
\hline $00: 00 \sim 08: 00$ & 44.8 & (11.5) & $21.0(14.2)$ & $1.8(3.5)$ & 20.0 & (8.9) & $36.0(17.9)$ & $60.0(7.2)$ \\
\hline \multicolumn{9}{|l|}{ Delayed shift sleep } \\
\hline $06: 00 \sim 14: 00$ & $60.3^{*}$ & $(7.3)$ & $10.4(9.5)$ & $10.8(7.4)$ & 48. $5^{* *}$ & $*(11.8)$ & $65.8(20.8)$ & 44. $3^{*}(10.9)$ \\
\hline $12: 00 \sim 20: 00$ & $65.8^{* *}$ & $*(7.8)$ & $13.5(7.2)$ & $4.5(9.0)$ & $35.8^{*}$ & $(8.8)$ & $47.0(17.7)$ & $57.8(10.6)$ \\
\hline $18: 00 \sim 02: 00$ & $66.3^{*}$ & $(10.8)$ & $17.0(10.1)$ & $4.8(5.6)$ & 32.8 & (9.5) & $42.8(22.7)$ & $50.4(16.3)$ \\
\hline $00: 00 \sim 08: 00$ & 59.5 & $(9.6)$ & $24.2(12.3)$ & $2.1(4.2)$ & 28.8 & $(7.8)$ & $40.5(16.5)$ & $55.7(8.9)$ \\
\hline \multicolumn{9}{|l|}{ Recovery night sleep } \\
\hline $00: 00 \sim 08: 00$ & 52.8 & $(5.4)$ & $8.0(9.7)$ & $1.8(3.5)$ & 23.3 & $(2.5)$ & $45.1(6.8)$ & $57.4(26.6)$ \\
\hline
\end{tabular}

${ }^{*} p<0.05,{ }^{* *} p<0.01$, significantly different from the baseline night sleep (one-tailed $t$-test).

すと，Fig.2 のと就りである．なお，各实験日の得点の 平均値および標準偏差の值は Table 4 に示してある. 各 実験日の平均得点の変化をみると，第 1 日は起床直後に 高い得点になるが，その後午前中はやや減少したのち， 午後は午前中のレベルを持続した。第 2 日では，午前中 㹥第 1 日の変化と同じであるが，午後はやや増大し，前 半夜から第 3 日の深夜の時間帯にかけて著しく増大し た. 第 3〜4日と第 4 5 日の変化は, 第 $2 \sim 3$ 日と覚 醒時刻は異なっているが，その变化とよく類 似してい た.

第 6 日は，それ以前にみられていた起床直後の高い得 点がみられず，深夜帯から午前 8 時まではほぼ一定の得 点を示した. しかし，午前 9 時より得点は增大して，そ の後は午後 5 時までわずかずつ増加する傾向であった。 そして，その後はさらに漸増するというパターンを示し た. 第 7 日は，起床後の高得点現象が再びあらわれ，ま た日中の得点レベルは第 1 日や第 2 日よりも明らかに高 く，かっ午後のレペルが前半夜まで継続していた．第 8 日は第 7 日よりも得点レベルは低いが，ほぼ同じ変化の 㑯向を示した。

睡眠かららの覚醒後得点 4 （ややぼんやりしている）に なるまでの所要時間は（起床直後のデータは除く）, 第 2 日は 15 時間，第 3〜4 日と第 4〜5日はそれぞれ9 時間であったが，第 6 日は 7 時間になり，さらに第 7 日 には 3 時間と激減した。

各実験日の SSS の平均得点を Table 4 に示した（起 㦿直後のデータを除く). 全実験日の得点レベルの間に は二元配居の分散分析で有意差はなかったか，実験第 1
Table 4. Mean scores of Stanford Sleepiness Scale and mean critical fusion frequencies for each of the experimental days.

\begin{tabular}{llccc}
\hline & & $N$ & $\begin{array}{c}\text { SSS } \\
\text { mean(SD) }\end{array}$ & $\begin{array}{c}\text { CFF } \\
\text { mean(SD) }\end{array}$ \\
\hline 1st & day & 16 & $2.7(0.3)$ & $36.2(1.2)$ \\
2nd-3rd day & 22 & $3.6(1.0)$ & $38.1(1.6)$ \\
3rd-4th & day & 22 & $4.1(0.8)$ & $37.8(1.4)$ \\
4th-5th & day & 22 & $4.1(0.9)$ & $38.4(1.5)$ \\
6th & day & 22 & $4.2(0.7)^{*}$ & $37.3(1.5)$ \\
7th & day & 17 & $4.0(0.5)$ & $35.9(0.4)^{* *}$ \\
8th & day & 10 & $3.6(0.4)$ & $36.0(0.7)^{* *}$ \\
\hline
\end{tabular}

SSS : Stanford Sleepiness Scale, CFF : critical fusion frequency in $\mathrm{Hz} .{ }^{*} p<0.05,{ }^{* *} p<0.01$, based on the 2nd-3rd day. The data measured on the wake-up time was omitted from the analysis.

日を基準にすると，その後の各実験日における平均得点 にはみな明らかな有意な增加 $(p<0.01)$ が喼められた。 また，第 $2 \sim 3$ 日と比較して，第 6 日の平均得点は有意 に增大していた $(p<0.01)$.

\section{3. フリッカー值の变化}

各実験日の平均フリッカー值は Table 4 に示すとおり である．全実験日の間には，有意な差がみられなかっ た. しかし，第 2〜3日を基準とすると，第 3〜4 日か ら第 6 日までは差がなかったが，第7日，第8日は有意 に低下していた.なお，各実験日のフリッカー值の変化 の特改については，別報9をを参照されたい。 

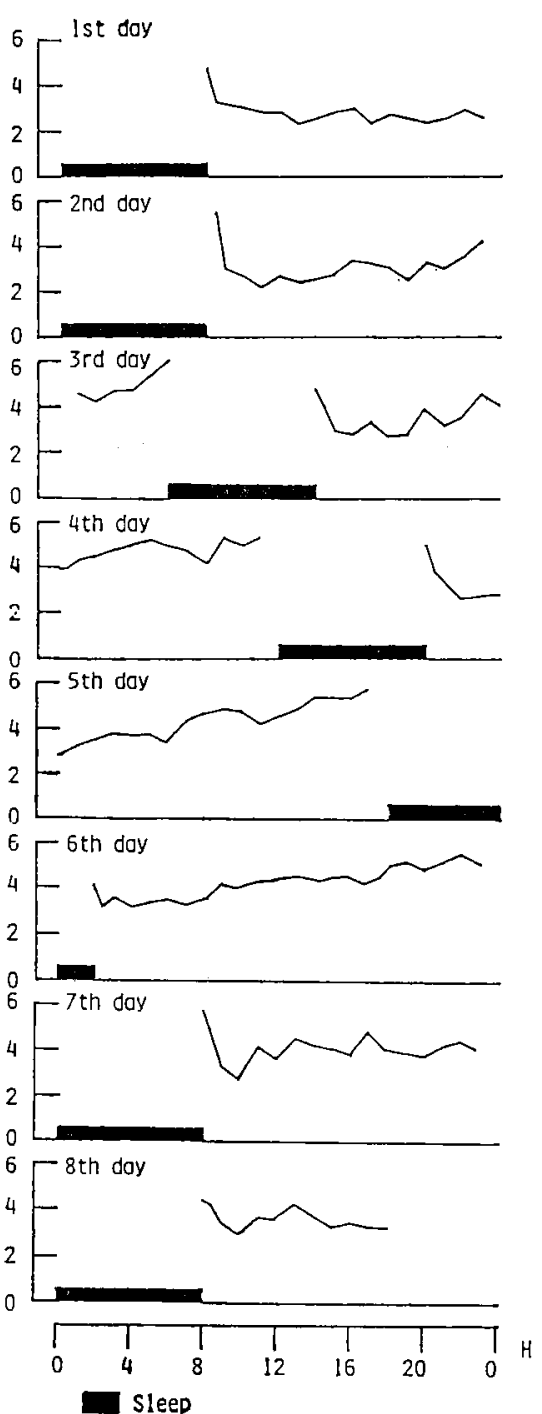

Fig. 2. Variations of average score of Stanford Sleepiness Scale for six subjects during the experimental days.

\section{IV. 考察}

まず，S4 の変化についてみると，第 3 日の睡眠中の S4 の出現量は基準夜とくらべて有意に”多く，それはと くに睡眠前期に顕著であった. また，そのときの S4の 潜時も有意な短縮がみられた. S3 については，潜時が 有意に短縮していたが，その出現量の増加はみられなか った. したがって，22時間の長時間覚醒はとくに S4 に 影響を及ばしたといえる。
本実驗では，第 3 日以降第 4 日，第 5 〜 日および第 7 日の睡眠は，いずれる22 時間の覚醒時間後であるが， 睡眠時刻はそれぞれ 6 時間ずつ後にずれている.いまま での多くの睡眠研究では，REM 睡腿は夜間の後半から 午前中にかけて增加し，午後から前半夜にかけて減少す るサーカディアンリズムを示すことが明らかにされてい る12 15). 本研究の結果でも，第 3 日の 06:00 14:00 の睡眠では， REM 睡眠は基準夜よりも 40 分以上の有 意な増加を示し，その後の $12: 00 \sim 20: 00,18: 00 \sim$ $02: 00$, および $00: 00 \sim 08: 00$ の各時間帯にほぼ 10 分 ずつの娍少がみられた.このサーカディアンリズムは， REM 睡眠潜時が漸次延長していくことにも認められた.

一方, SSS の得点の変化は, 覚醒 22 時間後の第 $3 \sim$ 4 日から第 6 日まで覚醒時間の経過とともに次第に増大 する傾向を示した. そして, 起床後平均得点が 4 点にな るまでの所要時間は次第に短縮し，かつ，第 6 日の平均 得点レペルは，第 $2 \sim 3$ 日のそれと比較して，有意に増 大していた.

このような実験期間中のSSSの変化にみられる覚醒レ ベルの顕著な低下傾向は，別報9で報告したフリッカー 值の変化にも同様に瑟められた.すなわら，第 $3 \sim 4$ 日，第 4〜 5 日打よび第 6 日は，それぞれ覚醒時間の後 半に著しい低下がみられ，起㦿後その顕著な低下が起こ るまでの時間が次第に短縮し，かつ第7日中第 8 日には 第 2 3 日と比較して覚醒時間全体で有意な低下がみら れた。

したがって，22 時間覚醒を繰り返すことによって，被 験者の覚醒レペルは明らかに低下していったということ ができる。

上述のように，第 3 日から第 7 日にかけての睡眠でサ 一カディアンリズムに従った REM 睡眠の隇少があらか しめ予想され，本実験の結果ですそれが推認された，し たがって，もし覚醒レベルの低下が S4 の増大と直接的 に関係しているならば，第 $3 \sim 4$ 日以降の各実験日の睡 眠には，第 $2 \sim 3$ 日と比較して，S4 の顕著な增大があ らわれることが考觉られる. しかし，本実験の結果は， Table 2 中 Table 3 に示すよ 5 に, S4 の全睡眠時間和 よび睡眠前期における出現量は，実験日を追って濑次增 大する傾向にあったが，その增大はそれほど大きないの ではなかった，さらに，第 $2 \sim 3$ 日とくらべてフリッカ 一值が有意に低下していた第 7 日後の回復夜（第 8 日） の S4 の全睡眠時間における出現量は，同じ時刻带の适 眠である基準夜のそれとほとんど同じであった。

以上の結果から，第 $2 \sim 3$ 日の後半に示された覚醒レ ベルの顕著な低下と第 3 日の睡眠の S4 の著しい增加, 
および入眠潜時，S3，S4 の各潜時などの明らかな短縮 との間には明確な関係があることが示唆されるが，その 後の 22 時間覚醒の繰り返し中に和ける覚醒レベルの顕 著な低下㑯向と S4 の出現量との間には直接的な関係は ないといえる。

このよ5に，覚醒レペルと S4 の出現量との間に明確 な関係がみられないことは，S4ゃ SWS に覚醒レペル の低下を直接的に示しにくいいくつかの特徵があるため と考えられる，それは，まず第 1 には，S4 の出現量は 先行覚醒時間の長さによって規定されてはいるが，両者 の関係は直線的ではないことがあげられる. Webb らつ は先行覚醒時間の長さと S4 の出現量との間に, 前者が 24 時間までは 1 時間当りの後者の出現量は大きな増大 を示すのにたいして，24 時間を越えるとその增加率は著 しく低下するといら関保があることを明らがした。

いくつかの断眠実験は，断眠時間が增大寸るにつれて 覚醒レベルがしたいに低下することを明らかにしてい

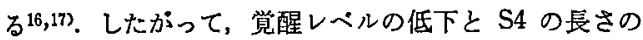
増大との間にもそれと同様な関係，すなわち，一定程度 の覚醒レベルの低下は S4 の増大と関連しているが，そ れ以上の低下は S4 の増大とは直接的には関係がないこ とが考觉られる。

第 2 K, S4 P SWS の回復作用の特徽考慮すべき ことである.すなわら、それらが長い覚醒のために失わ れる場合，上述のように，その後の睡眠によって回復し ようとする機能があるが，その回復の大きさを活活一定 にするよらな作用が働いていることが知られている。 Åkerstedt ら ${ }^{18)}$ は，夜間時の睡眠を $0 ， 2 ， 4 ， 8$ 時間 と変化させたときに，おのおのの睡眠でとられる SWS の時間とその後の昼間の睡眠でのその時間の和はほぼ一 定であることを示した，また，Karacan ら ${ }^{193}$ は，午前 2 時間，および午前 1 時間と午後 1 時間の 2 回に分けて 仮眠をとったときにおの和のの睡眠での S4 の出現量と その夜の睡眠での出現量との和は同じであることを明ら か炕した.こらしたことから，彼らはある長さの覚醒時 間のもとでは，S4 には一定の必要充足量があると考え ている.

本実験の結果では, 22 時間の覚醒の繰り返しによる各 実験日の S4 はいずれも 80 分台であったが，この出現 量は上述した Webb ら》の結果とほぼ同じである. し たがって，先行覚醒時間が 22 時間で腄眠か゚ 8 時間の条 件では, 必要とする S4 が十分充足されていたために, それ以上の S4 の出現がもたらされなかったと考壳られ ろ.

睡眠の機能については，現在まで多くの研究が行われ
てきた、そして，そのいくつかの研究は，睡眠が生体内 の組織修復過程であっで20,21)，その過程では生長ホルモ ンの放出やタンパク合成が行われて和り，とくに SWS がその過程で重要な役割を果たしていることを明らかに している22,23). 今後のこの種の研究の進展によって, 睡 眠の疲労回復に関するメカニズムがより明らかにされて いくと考觉られる。

さらに，疲労の回復過程に関して今後検討すべき課題 としては，覚醒中における疲労回復の効果の問題があ る. 序論にる指摘されているよ5に，産業学働や実験的 作業時に挿入される休想によって，労働の遂行などによ って低下した生理的な機能の回復がみられることは確か なことである．本実験では，覚醒時間中に被験者が行ら ことは,おもに生理心理諸機能の測定をうけることであ ったが，それ以外の時間にはかれらは読㗷，テレビやラ シオの視聴取などを行っていた。これらの活動中特よび それらの合間に疲労の回復過程が作用していることが考 えられる.したがって，今後睡眠による疲労回復効果を 検討する場合には，覚醒時間中のその種の効果を統制し ながら行っていくことが必要であるう。

\section{V. 結 論}

22時間の覚醒時間によって生ずる大脳皮質の覚醒レべ ルの低下は，その後の睡眠で S4 の増大をもたらすが， 同じ 22 時間の覚醒の繰り返しによる覚醒レベルの著し い低下は，その後の各睡眠での S4 の一層の增大をるた らさない.

本論文の一部は，第 54 回日本産業郝生学会で発齐した。

\section{文献}

1) Horne JA. Sleep loss: Underlying mechanisms and tiredness. In : Folkard S, Monk $\mathrm{TH}$, eds. Hours of work. Chichester : John Wiley \& Sons, $1985: 53-65$.

2) Chauchard P. La fatigue. (ショシャール. 波労. 内溒耕二訳. 東京 : 白水社, 1972.)

3) Shapiro CM, Griesel RD, Bartel PR, Jooste PL. Sleep patterns after graded exercise. J Appl Physiol $1975 ; 39: 187-190$.

4) Matsumoto K, Saito $Y$, Furumi K, Abe M. Ef fect of night exercise during 27-hr total sleep deprivation on the subsequent sleep. Percept Motor Skills $1985 ; 60: 915-924$.

5) Glaubman $H$, Orbach I, Gross $Y$, et al. The effects of presleep focal attention load on subsequent sleep patterns. Psychophysiology 1979; 16: 467-470.

6) Browman CP, Tepas DI. The effect of presleep activity on all night sleep. Psychophysiology 1976; 
$13: 536-540$.

7) Webb WB, Agnew HW. Stage 4 sleep : influence of time course variables. Science $1971 ; 174: 1354-$ 1356.

8) Horne JA. A review of the biological effects of total sleep deprivation in man. Biol Psychol 1978; $7: 55-102$.

9）斎藤良夫，松本一弥，睡眠時刻の推移にとるなら生理・ 心理諸機能の変動とそ玌らの関係，産業医学 $1988 ; 30$ (3) : 192-201.

10) Rechtschaffen A, Kales A, eds. A manual of standardized terminology techniques and scoreing system for sleep stages of human subjects. Washington DC : US Government Printing Office, 1968.

11) Hoddes E, Zarcone V, Smythe $H$, et al. Quantification of sleepiness: A new approach. Psychophysiology $1973 ; 10: 431-436$.

12) Karacan I, Finley WW, Williams RL, Hursch CJ. Changes in stage 1-REM and stage 4 sleep during naps. Biol Psychiat $1970 ; 2: 261-265$.

13) Taub JM, Berger RJ. Sleep stage patterns associated with acute shifts in the sleep-wakefulness cycle. EEG Clin Neurophysiol 1973 ; $35: 613-619$.

14）遠藤四郎，西原宗子，相沢一郎，小田 潤. 健康成人の 昼間睡眠と入眠時刻の影響. 臨床脳波 $1976 ; 18: 1-10$.

15) Webb WB, Agnew HW. Sleep cycling within twenty-four hour periods. J Exp Psychol 1967 ; 74 : 158-160.

16) Malmo RB, Surwillo WW. Sleep deprivation: changes in performance and physiological indicants of activation. Psychol Monogr $1960 ; 74$ : No. 15.

17) Kollar FJ, Pasnau RO, Rubin RT, et al. Psychological, psychophysiological and biochemical cor. relates of prolonged sleep deprivation. Am J Psychiat $1969 ; 126: 488-497$.

18) Akerstedt T, Gillberg MA. Dose-response study of sleep loss and spontaneous sleep termination. Psychophysiology $1986 ; 23$ : 293-297.

19) Karacan I, Williams RL, Finley WW, Hursch CJ. The effects of naps on nocturnal sleep : influence on the need for stage-1 REM and stage 4 sleep. Biol Psychiat 1970 ; 2 : 391-399.

20) Adam K. Sleep as a restorative process and a theory to explain why. Prog Brain Res 1980 ; 53: 289-306.

21) Adam K, Oswald I. Sleep is for tissue restoration. J R Coll Physicians $1977 ; 7: 115-125$.

22) Horne JA. The effects of exercise upon sleep: a critical review. Biol Psychol $1981 ; 12: 241-290$.

23）鳥居鎮夫. 睡眠の穖能. 鳥居鎮夫 編. 睡眠の科学. 東 京：朝倉書笘 $1984 ： 1-31$.

著者への連絡先：斉藤良夫, $\bar{T} 192-03$ 八王子市束中野 742 中央大学文学部心理学研究室 Reprint requests to Department of Psychology, Chuo University, Higashi-nakano, Hachioji, Tokyo, 192-03 Japan (Y. Saito) 